\title{
Percutaneous closure of a paravalvular leak: a case report
}

\section{Morena Kvaternik*, Pavica Stanišić, Ružica Višnjovski}

University Hospital Centre Rijeka, Rijeka, Croatia
RECEIVED:

January 30, 2018

ACCEPTED:

February 10, 2018

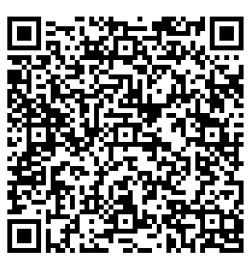

$\square$ Cardiologia Croatica 2018:13(1-2):58.
KEYWORDS: paravalvular leak, percutaneous closure of paravalvular leak, minimally invasive method. CITATION: Cardiol Croat. 2018;13(1-2):58. | https://doi.org/10.15836/ccar2018.58

*ADDRESS FOR CORRESPONDENCE: Morena Kvaternik, Klinički bolnički centar Rijeka, Krešimirova 42, HR-51000 Rijeka, Croatia. / Phone: +385-91-7349-766 / E-mail: morena.1207@gmail.com

ORCID: Morena Kvaternik, https://orcid.org/0000-0001-8510-1633 • Pavica Stanišić, https://orcid.org/0000-0003-4460-4888 Ružica Višnjovski, https://orcid.org/0000-0002-9496-0680

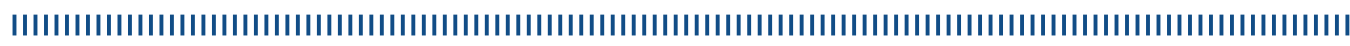

Paravalvular leak after artificial valve implantation is rare but serious complication. The patients are usually older, with a lot of comorbidities and surgical approach is connected with large perioperative risk and possible failure. Percutanous closure is minimally invasive method and very efficient. As the number of patients with implanted valves is growing, there will be increased need for these interventions. ${ }^{1,2}$

We are presenting a case of percutaneous closure of aortic paravalvular leak in a younger female patient, using Occlutech's nitinol mesh occluder (PLD Occluder 63PLD07T).

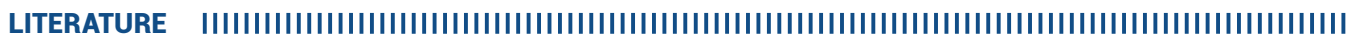
1. Mirat J, Córić V, Bernat R, Vrbanić L, Vrljić D, Vojković J, et al. Valvular heart diseases in Croatia in 2011. Cardiol Croat. 2012;7(3-4):57-64. Available at: http://www.kardio.hr/pdf/Kardio\%20list\%202012_73-4_59-64.pdf

2. Pibarot P, Dumesnil JG. Prosthetic heart valves: selection of the optimal prosthesis and long-term management. Circulation. $2009 \mathrm{Feb}$ 24;119(7):1034-48. https://doi.org/10.1161//IRCULATIONAHA.108.778886 